\title{
EFFICIENCY OF THE SPAW MODEL IN ESTIMATION OF SATURATED HYDRAULIC CONDUCTIVITY IN CALCAREOUS SOILS
}

\author{
TARIQ H. KARIM ${ }^{*}$ and MOHAMMED A. FATTAH ${ }^{* *}$ \\ *Dept. of Soil and Water Science, College of Agricultural Engineering Sciences, \\ University of Salahaddin, Kurdistan Region-Iraq. \\ ** Dept. of Natural Resources, College of Agricultural Engineering Sciences, \\ University of Sulaimani, , Kurdistan Region-Iraq.
}

(Received; September 22, 2020 ; Accepted for Publication: November 15, 2020 )

\begin{abstract}
The measurement of soil hydraulic properties is tedious, time-consuming, and costly. An alternative approach is to formulate models that utilize the physical and chemical properties of the soil as input variables to predict soil saturated hydraulic conductivity $\left(K_{s}\right)$. However, the previous studies have not paid attention to the calcium carbonate content in their models; it can lead to reducing the size and number of the pores in the soil which, in turn, can lead to reduction $K_{s}$. Here we evaluated the ability of the Soil, Plant, Atmosphere, and Water (SPAW) model to predict $\mathbf{K}_{\mathrm{s}}$ under different states of compaction for calcareous soils with wide-ranging textures sampled along a precipitation gradient in northwestern Iraqi Kurdistan. The results revealed that the best match occurred under loose to normal state of compaction for these soils. Among the soil properties, sand content was high significantly correlated with $\mathrm{K}_{\mathrm{s}}$ followed by $\mathrm{CaCO}_{3}$, clay, organic matter content, silt and Electrical conductivity. A pedotransfer function (PTF) was proposed using these data and its results were compared to these from the SPAW model. Root mean square error (RMSE) and coefficient of variation (CV) for the comparison between measured $K_{s}$ values and those predicted by the SPAW model were very high $2.7 \times 10^{-4} \mathrm{~cm} \mathrm{~s}^{-1}$ and $166 \%$ respectively, that due to the values of Ks predicted by the SPAW model are overestimated for calcareous soils, for these reasons the accuracy of the SPAW model was improved via calibration. The RMSE and CV of the calibrated SPAW model were dropped to $9.8 \times 10^{-5} \mathrm{~cm} \mathrm{~s}^{-1}$ and $61.2 \%$, respectively. Additionally, the accuracy of our best PTF that constructed from sand, clay, and $\mathrm{CaCO}_{3}$ was slightly higher than the calibrated SPAW model. Therefore, it is recommended to use the calibrated SPAW model for predicting $\mathbf{K}_{\mathrm{s}}$ in calcareous soils.
\end{abstract}

KEYWORDS: Pedotransfer functions; SPAW model; Model calibration; calcareous soils.

\section{INTRODUCTION}

B ecause saturated hydraulic conductivity $\left(\mathrm{K}_{\mathrm{s}}\right)$ influences efficient management of soil and water, it is considered to be an important soil hydraulic parameter in large- and small-scale hydrologic studies (Ahmadi and Sepaskhah, 2012). The determination of soil hydraulic properties in past decades has required extensive laboratory procedures. These procedures are cumbersome, time- and energyconsuming, and costly. Accordingly, intensive efforts are being made to develop predictive relationships (Igbadun et al., 2011). The relationships between soil properties different in difficulty of their measurement or their availability are known as pedotransfer functions (PTFs) (Pachepsky and Van Genuchten, 2011). These functions fill the gap between the available soil data and the properties which are more useful (Bouma, 1989). Numerous studies over the years have formulated models using measured physical and chemical properties of the soil as input variables (Saxton and Rawls 2006; Salarashayeri and Siosemarde, 2012). However, the previous researchers have not paid attention to the content of calcium carbonate in their models. Generally, calcareous soils have a high micromass of calcium carbonate which is occurring in the form of micritic or microsparitic crystals (Durand et al., 2018). The b-fabric (crystallitic) is small bright formations (Stoops, 2003). This fabric can develop in soils and gradually precipitate in the clayey micromass, and consequently, the pore space among soil particles and aggregates are progressively filled by it; also calcitic coatings around quartz minerals (Monger et al., 1991). This can lead to

$$
\text { solavtariq@yahoo.com; muhammad.fattah@univsul.edu.iq }
$$


reducing the size and number of the pores in the soil which, in turn, can lead to a severe reduction in the soil's hydraulic conductivity. Since the average values of calcium carbonate in Iraqi Kurdistan soils are more than $20 \%$ (i.e. calcareous soils) Faraj (2017) therefore, formulating models containing the average values of the calcium carbonate might lead to a more realistic outcome.

The agro-hydrological model Soil, Plant, Atmosphere, and Water (SPAW) is a numerical model that is based on the Richards equation and has been used with varying degrees of success to assess components of the field water cycle (Song et al., 2009). It has been applied and examined under varying conditions and locations (Ma et al., 2011). The Soil Water CharacteristicHydraulic Properties Calculator (SWC-HPC) represents a component of SPAW (Saxton and Rawls, 2006) that can be used for predicting the transmission characteristics of soil horizons. The key input variable needed is particle-size distribution, particularly the clay and sand components. Additional variables that can be used to improve the level of performance of the model are soil organic content, soil salinity, rock fragments, and soil bulk density as an indicator of soil compaction state (i.e. loss, normal, dense, hard, and sever) (Igbadun et al., 2011).

The $K_{\mathrm{s}}$ of soils with rock fragments can be reasonably-well related to the $K_{s}$ of the fine fraction $(<2 \mathrm{~mm})$ using the weight of the rock (>2 mm) fragments (Brakensiek et al., 1986; Renard et al., 1997). This means that the $\mathrm{K}_{\mathrm{s}}$ of the soil without rock fragments and the weight percent of rock fragments in a soil can be used to be estimating the change in permeability class (Renard et al., 1997). For conditions in which repeated disturbance leaves the soil in a loose state, for example, after continuous cattle grazing, the $\mathrm{K}_{\mathrm{s}}$ in the disturbed state governs soil infiltration. Under most cases, the available data on $\mathrm{K}_{\mathrm{s}}$ are from disturbed soil samples. Since the SPAW model is optimized for a certain location and condition and there is no guarantee to give accurate results when applied elsewhere, the calibration of this model is required. Since the soil porosity reaches its maximum value directly after disturbance and decays exponentially to a normal value at the end of the growing season, and the soil is in a loose to normal condition most of the time, the current study was conducted with the following goals: (1) to develop a pedotransfer function to predict $\mathrm{K}_{\mathrm{s}}$ from other soil properties in calcareous soils; (2) to evaluate the SPAW model for estimating the $\mathrm{K}_{\mathrm{s}}$ in soil in loose to normal states of compaction; and (3) to improve the prediction accuracy by calibrating the SPAW model to local conditions of the study area which have wide range of sand and clay contents in calcareous soils.

\section{MATERIALS AND METHODS 2.1 Site Description}

The study area was located in Iraqi Kurdistan Region-Sulaimani Province and its surrounding area. The sampling sites have latitude between $34^{\circ} 25^{\prime} 00^{\prime \prime}$ to $36^{\circ} 25^{\prime} 00^{\prime \prime}$, the longitude between $44^{\circ} 25^{\prime} 00^{\prime \prime}$ to $46^{\circ} 25^{\prime} 00^{\prime \prime}$, and the altitude ranges from $220 \mathrm{~m}$ at the southern boundary to more than $1200 \mathrm{~m}$ on the Iranian border. The climate is semiarid Mediterranean with rainy and cold winters followed by hot and dry summers; the precipitation falls between October and May. The annual rainfall ranges from as low as 200 $\mathrm{mm}$ in the south of Sulaimani governorate to as high as $800 \mathrm{~mm}$ in the mountainous area at the Iraqi-Iranian border (Najmaddin et al., 2017). Overall, there is surplus water from November to mid-April. Physiographically, the wide plains are intermontane valleys with high agricultural potential and are cultivated using dry farming techniques; wheat and barley are the principal crops. There are scattered areas of irrigated land with vegetables, fruit crops, and some field crops, specifically in narrow strips along the rivers and the main streams. The dominant soils can be categorized as Vertisols, Mollisols, Inceptisols, and Entisols. The areas surrounding the wide plains are rolling hills or mountains that are part of the Zagros mountain range. The mountains mainly consist of various kinds of limestones, with no exception, all the soils at this site are calcareous, and the lime content is usually over $20 \%$ (Abedakarim, 2015). There are also scattered patches of red mudstone, blue marl, and chalk belonging to the Gercus, Kolosh, and Shiranish formations (Aziz, 2002).

\subsection{Soil Sampling Strategy}

Disturbed soil samples were taken in duplicate from the surface layer $(0-30 \mathrm{~cm})$ of 30 different sites across the wide plains and the mountainous area of Sulaimani Province. They were selected to cover a wide range of annual rainfall values and to obtain a broad range of soil physical and chemical properties. After soil samples were obtained, they were brought to the laboratory, air-dried, ground to pass through a 2- 
mm sieve, and kept in plastic containers until analysis.

\subsection{Methods of Soil Analysis}

Particle-size distribution was performed using the sieving and pipette methods as described by Klute (1986). Soil organic matter content was determined using the wet oxidation method of Walkley and Black as outlined by Nelson and Sommers (1982). Acid neutralization method was used for determining calcium carbonate $\left(\mathrm{CaCO}_{3}\right)$ contents according to Richards as described in Rowell (1996). The $\mathrm{EC}_{\mathrm{e}}$ was measured at the reference temperature $25^{\circ} \mathrm{C}$ with an EC meter following the procedure described by Van Reeuwijk (1995).

\subsection{Measurement of Saturated Hydraulic Conductivity}

The $\mathrm{K}_{\mathrm{s}}$ of each soil was measured by a device constructed for this purpose. To achieve this goal, a perforated metal screen was fitted to the base of a metal a cylinder $5 \mathrm{~cm}$ in diameter and $40 \mathrm{~cm}$ in height. A filter paper was then placed over the screen to prevent migration of fine particles during the test. Subsequently, a disturbed sample of each soil was poured into the cylinder. During soil packing, the cylinder was tapped 25 times against the bench surface to obtain a stable soil column. The achieved soil bulk density values corresponded to $0.9-1.0$ of their insitu values. Another filter paper was also placed over the soil surface to minimize soil disturbance before exerting a constant head of about $15 \mathrm{~cm}$. The assembly was held in a vertical position using a wooden frame. The soil columns were set in duplicate in the laboratory at a room temperature of $30 \pm 2^{\circ} \mathrm{C}$. After reaching the soil columns to saturated state, the data of effluent water was recorded of each sample for a period of $1 \mathrm{hr}$. Having measured the water discharge, Darcy's law, which takes the following form, was applied to determine the $\mathrm{K}_{\mathrm{s}}$ of each soil (Eq. 1):

$$
K_{s}=\frac{Q \Delta L}{A \Delta H}
$$

Where: $\mathrm{K}_{\mathrm{s}}$ is saturated hydraulic conductivity $\left(\mathrm{cm} \mathrm{hr}^{-1}\right), \Delta \mathrm{L}$ is the soil column length $(\mathrm{cm}), \mathrm{A}$ is the cross-sectional area $\left(\mathrm{cm}^{2}\right)$, and $\Delta \mathrm{H}$ is the difference in hydraulic head across the column ends $(\mathrm{cm})$. Finally, $\mathrm{K}_{\mathrm{s}}$ was adjusted to $20^{\circ} \mathrm{C}$ following to Klute (1986).

\subsection{Simulation Procedure}

The performance of the SPAW model was tested by inputting the percentages of clay and sand, together with the percentage of organic matter and soil salinity for each site. Since the soil samples passed through a $2 \mathrm{~mm}$ sieve, the soil gravel content was set at zero. The degree of compaction was set to $90-100 \%$ of normal, since the soil had been stabilized and compacted, as mentioned earlier. Additionally, Microsoft ${ }^{\circledR}$ Excel and NCSS 12 (NCSS 12.0.2 Statistical Software 2015) were used to determine the parameters of the linear relationship between $\mathrm{K}_{\mathrm{s}}$ and each of the following variables: sand, silt, clay, organic matter, electrical conductivity of the saturated extract $\left(\mathrm{EC}_{\mathrm{e}}\right)$, and $\mathrm{CaCO}_{3}$ equivalent.

\subsection{Efficiency Criteria}

A suite of efficiency criteria were used to test the performance of the SPAW model. These statistics were (Eqs. 2-7) (Krause et al., 2005).

$$
\begin{aligned}
& C V=\frac{\sqrt{\frac{1}{d f_{\text {error }}} \sum_{i=1}^{n}\left(O_{i}-P_{i}\right)^{2}}}{\bar{O}} \times 100 \ldots \ldots \ldots \\
& R M S E=\sqrt{\frac{1}{d f_{\text {error }}} \sum_{i=1}^{n}\left(O_{i}-P_{i}\right)^{2}} \\
& E F=1-\frac{\sum_{i=1}^{n}\left(O_{i}-P_{i}\right)^{2}}{\sum_{i=1}^{n}\left(O_{i}-\bar{O}\right)^{2}} \\
& C R M=\frac{\sum_{i=1}^{n} O_{i}-\sum_{i=1}^{n} P_{i}}{\sum_{i=1}^{n} O_{i}} \\
& M A E=\frac{\left.\sum_{i=1}^{n}\left[\mid O_{i}-P_{i}\right]\right]}{n} \\
& A A P E=\frac{1}{n} \sum_{i=1}^{n}\left|\frac{O_{i}-P_{i}}{O_{i}}\right| \times 100
\end{aligned}
$$

where $\mathrm{CV}$ is coefficient of variation, $\mathrm{O}_{\mathrm{i}}$ is $\mathrm{i}^{\text {th }}$ observed value, $P_{i}$ is predicted $i^{\text {th }}$ value, $n$ is the number of observations, $\overline{0}$ is the mean of observed values; $\mathrm{df}_{\text {error }}$ is degrees of freedom; RMSE is the root mean square error, EF is the modeling efficiency, CRM is the coefficient of residual mass, MAE is the mean absolute error, and AAPE is the average absolute percent error.

\subsection{Model Calibration}

Linear regression analysis was performed to calibrate the SPAW model to the conditions and properties of the samples. The calibration was made after plotting the measured $K_{\mathrm{s}}$ as the dependent variable versus the predicted values from SPAW model. The predicted values from the regression model were plotted versus the predicted value from SPAW model. It is

$$
\text { solavtariq@yahoo.com; muhammad.fattah@univsul.edu.iq }
$$


interesting to mention that the regression line was not forced to pass through the origin.

\section{RESULTS AND DISCUSSION}

\subsection{Correlation Analysis}

The measured $\mathrm{K}_{\mathrm{s}}$ was correlated as a dependent variable against an array of input variables (Figure 1). The variables that positively and significantly $(\mathrm{P} \leq 0.01)$ correlated with the measured $\mathrm{K}_{\mathrm{s}}$ were sand content and $\mathrm{CaCO}_{3}$ content. Conversely, organic matter and clay content were negatively and significantly correlated $(\mathrm{P} \leq 0.01)$ with measured $\mathrm{K}_{\mathrm{s}}$ as was silt content $(\mathrm{P} \leq 0.05)$. These findings are in close agreement to those found by Khalaf (2010) for soils across the region of Iraqi Kurdistan. Among the study input variables, sand and $\mathrm{EC}_{\mathrm{e}}$ exhibited the strongest and the weakest correlation coefficients, respectively. Thus, sand content appeared to govern soil $\mathrm{K}_{\mathrm{s}}$.
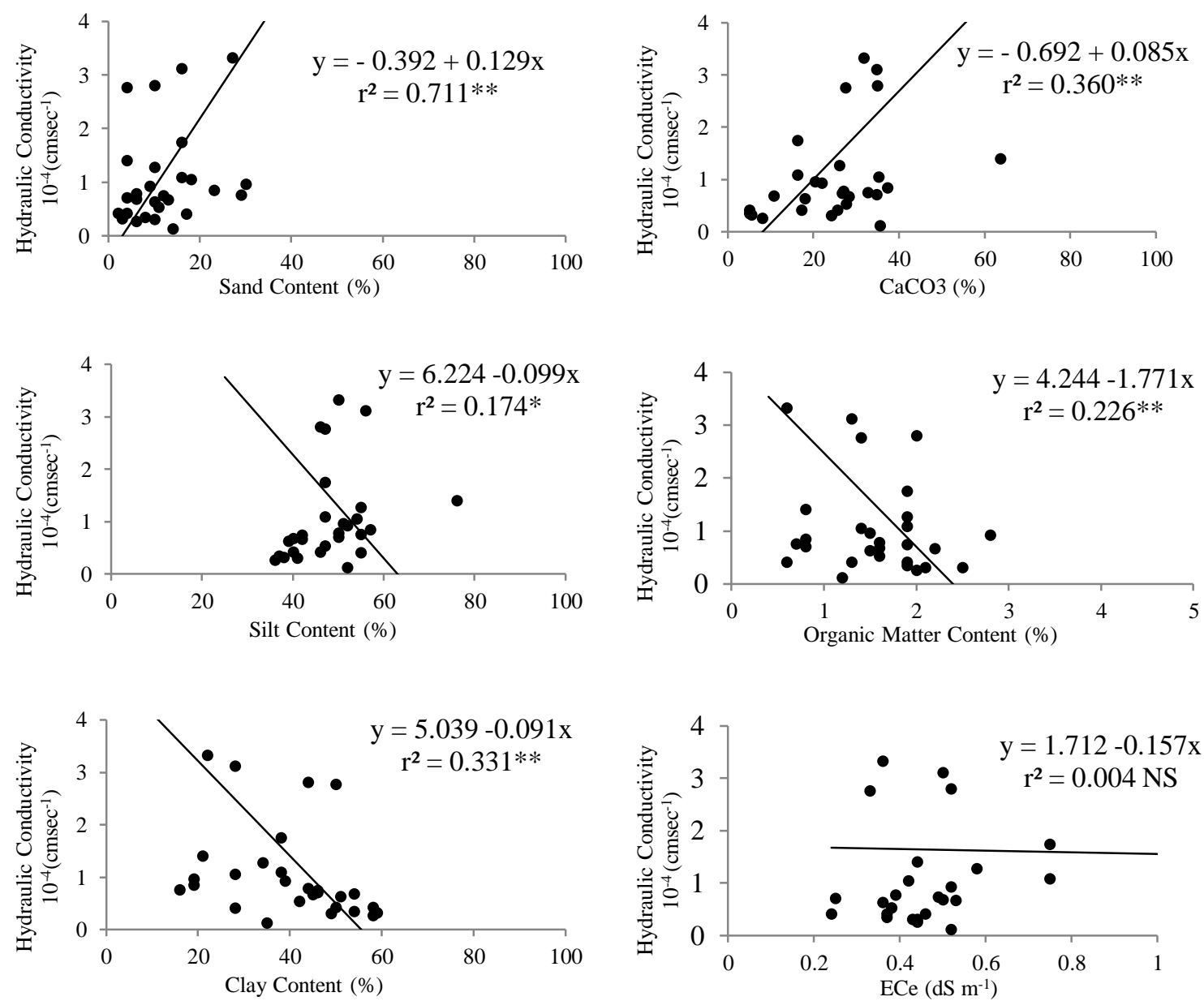

Fig. (1): Relationships between measured saturated hydraulic conductivity and selected physical and chemical soil properties.

\subsection{Local Empirical Models Used to Predict Saturated Ks from Other Soil Properties}

An effort was also made to predict $\mathrm{K}_{\mathrm{s}}$ from particle size distribution, organic matter (OM), and $\mathrm{CaCO}_{3}$ using regression analysis (NCSS 12 statistical software), and the results are displayed in Table 1.

In this study, there were 12 models $(2,6,10,11$, $12,16,17,21,22,23,25$, and 27) out of the available
27 models, the silt content shared in making them; While, they are unacceptable for predicting $\mathrm{K}_{\mathrm{s}}$ because silt had the lowest $r^{2}$ value of 0.1741 and the highest RMSE and AAPE values of 2.119507E-04 and 216.02 respectively (Table 1 ). Input like silt can't improve the accuracy of prediction of $K_{s}$ where there is a weak relationship between silt and $\mathrm{K}_{\mathrm{s}}$; in addition, the $\% \mathrm{CV}$ value of silt was low, equal to $20.70 \%$, when compared with the sand and clay variables, as shown in Table 2. Also it may lead to 
creating multicollinearity problem when shared with both sand and clay.

Among the one-parameter models, model 1 offered the best performance. The RMSE was $1.253171 \mathrm{E}-04$, while the level of dispersion between the measured and predicted values was $78.10 \%$. To further improve the accuracy of prediction, twoparameter models were also tested to predict Ks; the results indicate that model 9 exhibited the highest performance. Model 9 was constructed after inserting $\mathrm{CaCO}_{3}$ as an additional variable; as a result, the accuracy of prediction improved, and the coefficient of determination increased from 0.71128 to 0.7456 , while RMSE decreased from $1.253171 \mathrm{E}-04$ to 1.197923E-04. Among the three-parameter models, model 19 exhibited the highest performance. The coefficient of determination increased from 0.7456 to 0.8257 by addition of the clay variable to model 9 ; the RMSE decreased from 1.197923E-04 to 1.010537E-04. Four-parameter models were also tested to predict $\mathrm{K}_{\mathrm{s}}$; the results indicated that model 26 exhibited the most acceptable results among the four independent variable models. The coefficient of determination slightly increased when compared with model 19, while RMSE and AAPE also slightly increased (Table 1). Therefore, model 19 can be recommended as a pedotransfer function to predict $\mathrm{K}_{\mathrm{s}}$ in the area under study. Model 19 yielded close to the lowest values of RMSE, \%CV, and AAPE:

$$
\begin{aligned}
& K_{s}=-5.757 \times 10^{-4}+1.591 \times 10^{-5} \mathrm{SA}+8.545 \\
& \times 10^{-6} \mathrm{CL}+6.119 \times 10^{-6} \mathrm{CC} \\
& \text { 3.3Saturated Hydraulic Conductivity }
\end{aligned}
$$

Based on the measured and predicted values of $\mathrm{K}_{\mathrm{s}}$ of the study soils in a loose to normal state of compaction, the soils were categorized into different classes for specifying their proper uses (Figure 2). All the measured soil $\mathrm{K}_{\mathrm{s}}$ values fell in moderately low and moderately high classes according to Burt (2014). No class fell into very low, low, high, and very high classes.

These results are in accord with the findings of Khalaf (2010), who observed that during the first day of $\mathrm{K}_{\mathrm{s}}$ measurement in a disturbed state, the moderate class had the highest frequency. Regarding the values predicted by the SPAW model, there was a substantial increase in the number of samples that fell in the moderately high class, and two soils fell in the high class. This indicates that the SPAW model overestimated the actual $\mathrm{K}_{\mathrm{s}}$. The predicted $\mathrm{K}_{\mathrm{s}}$ values were neither positively nor negatively skewed. Additionally, the distribution of $\mathrm{K}_{\mathrm{s}}$ values predicted by the calibrated model was close to the distribution of the measured values, reflecting the reliability of the calibrated model. While the majority of the studied soils were characterized by a heavy texture, no soil fell in the very low or low classes. The greater stability of soil aggregates of the calcareous finely textured soils probably contributed to their higher $\mathrm{K}_{\mathrm{s}}$. These findings support the report of AAFRD (1996), they reported that the presence of calcium causes the soil structure to change, resulting in a cubic-like structure, which is porous and permits losses.

\subsection{Measured Ks Values and Values Predicted by the SPAW Mode}

IFigure 3 shows a comparison between the measured $K_{\mathrm{s}}$ and the values predicted by the SPAW model. The dashed line represents the potential 1:1 relationship between these two data sets. As shown in Figure 3, the two data sets are in good agreement with each other. There is no a high departure from 1:1 line. Additionally, Table 3 shows some selected statistical indices for comparison between the measured values and the values predicted by the SPAW model. The RMSE is $2.664 \mathrm{E}-04$, and the mean absolute error is $1.712 \mathrm{E}-04 \mathrm{~cm} \mathrm{~s}^{-1}$, while the level of dispersion as reflected by $\% \mathrm{CV}$, and based on the Wilding (1985) classification, is high and exceeds $166.04 \%$. The modeling efficiency as shown in Table 3 has a negative value $(-0.305)$. This implies that the SPAW model did not predict the $\mathrm{K}_{\mathrm{s}}$ at the desired level. The CRM revealed that this model over predicted $\mathrm{K}_{\mathrm{s}}$ by about $222 \%$.

\subsection{Calibration of SPAW ModelTo}

improve the accuracy of $\mathrm{K}_{\mathrm{s}}$ value prediction, the measured $\mathrm{K}_{\mathrm{s}}$ as the dependent variable was plotted versus the predicted $\mathrm{K}_{\mathrm{s}}$ from the SPAW model as the independent variable in loose to normal compaction condition to better suit the condition of the study area (Figure 4). It is apparent from Figure 4 that the relationship between the calibrated SPAW values and the predicted values from SPAW can be represented by the following linear relationship:

$$
\begin{aligned}
\mathrm{Ks}_{\text {SPAW,cal }}=- & 0.00000416 \\
& +0.525849 \mathrm{Ks}_{\text {SPAW }}
\end{aligned}
$$




\begin{tabular}{|c|c|c|c|c|c|c|c|c|c|c|c|}
\hline \multirow{2}{*}{$\begin{array}{c}\text { Model } \\
\text { classificati } \\
\text { on } \\
\end{array}$} & \multirow{2}{*}{$\begin{array}{c}\text { Mod } \\
\text { el } \\
\text { no. }\end{array}$} & \multirow[b]{2}{*}{ Intercept } & \multicolumn{5}{|c|}{ Slope } & \multicolumn{4}{|c|}{ Efficiency criteria } \\
\hline & & & Sand & Silt & Clay & O.M & $\mathrm{CaCO}_{3}$ & $\mathbf{R}^{2}$ & RMSE & CV & $\begin{array}{c}\text { AAP } \\
\text { E }\end{array}$ \\
\hline \multirow{10}{*}{$\begin{array}{c}\text { One } \\
\text { parameter }\end{array}$} & \multirow{2}{*}{1} & -3.91639 & 1.29062 & & & & & 0.7112 & 1.25317 & \multirow{2}{*}{78.10} & 128.8 \\
\hline & & E-05 & E-05 & & & & & 8 & $1 \mathrm{E}-04$ & & 3 \\
\hline & \multirow{2}{*}{2} & 6.22384 & & -9.88443 & \multirow{2}{*}{ - } & \multirow{2}{*}{-} & \multirow[b]{2}{*}{-} & 0.1741 & 2.11950 & 132.1 & 216.0 \\
\hline & & $E-04$ & - & E-06 & & & & 0 & $7 \mathrm{E}-04$ & 0 & 2 \\
\hline & \multirow{2}{*}{3} & 5.03915 & \multirow{2}{*}{ - } & \multirow{2}{*}{-} & -9.06236 & & - & 0.3307 & 1.90801 & 118.9 & 156.1 \\
\hline & & $\mathrm{E}-04$ & & & E-06 & - & - & 0 & $1 \mathrm{E}-04$ & 2 & 6 \\
\hline & 4 & 4.24348 & & & -5 & -1.77112 & & 0.2258 & 2.05198 & 127.8 & 186.0 \\
\hline & 4 & E-04 & 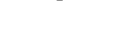 & 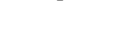 & 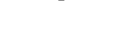 & E-04 & 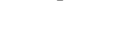 & 8 & $4 \mathrm{E}-04$ & 9 & 3 \\
\hline & & - & & & & & 8.452079 & & 1.86549 & 116.2 & 171.3 \\
\hline & 5 & $\begin{array}{c}6.916348 \\
E-05\end{array}$ & - & - & - & - & E-06 & 0.3602 & $5 \mathrm{E}-04$ & 7 & 1 \\
\hline & 6 & 1.19839 & 1.21779 & -3.16130 & & & & 0.7268 & 1.24134 & 7737 & 127.7 \\
\hline & 0 & E-04 & E-05 & E-06 & - & - & - & 2 & $1 \mathrm{E}-04$ & 17.01 & 8 \\
\hline & 7 & -2.09621 & 1.55139 & & 3.43336 & & & 0.7297 & 1.23476 & 7606 & 128.6 \\
\hline & $r$ & E-04 & E-05 & - & E-06 & - & - & 1 & $9 \mathrm{E}-04$ & 10.90 & 0 \\
\hline & 8 & -2.63630 & 1.27494 & & & -6.96425 & & 0.7115 & 1.27562 & 7950 & 128.5 \\
\hline & 0 & E-05 & E-05 &  & - & E-06 & - & 2 & 7 E-04 & 19.50 & 4 \\
\hline & & - & 1.115918 & & & & 3.064502 & & 1.19792 & & 141.2 \\
\hline & 9 & $\begin{array}{c}9.539622 \\
E-05\end{array}$ & E-05 & - & - & - & E-06 & 0.7456 & $3 \mathrm{E}-04$ & 14.66 & 4 \\
\hline & & 1.34094 & & -1.54019 & -1.21560 & & & 0.7148 & 1.26820 & & 127.1 \\
\hline & 10 & E-03 & - & E-05 & E-05 & & - & 7 & 5 E-04 & 79.04 & 0 \\
\hline Two & & 1.02475 & & -1.19194 & & -2.06217 & & 0.4729 & 1.72423 & 107.4 & 203.9 \\
\hline parameters & 政 & E-03 & 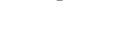 & E-05 & - & E-04 & & 4 & 7 E-04 & 6 & 7 \\
\hline & 12 & 5.510793 & & $\begin{array}{c}- \\
152721\end{array}$ & & & $1.07148 \mathrm{E}$ & 07120 & 1.27112 & ?ח ר 7 & 146.1 \\
\hline & 12 & $E-04$ & - & E-05 & - & - & -05 & 0.7100 & $3 \mathrm{E}-04$ & $19 .<2$ & 6 \\
\hline & 13 & 5.30841 & & & -7.30577 & -6.27520 & & 0.3466 & 1.91975 & 119.6 & 152.4 \\
\hline & 政 & E-04 & & & E-06 & E-05 & & 3 & $9 \mathrm{E}-04$ & 5 & 7 \\
\hline & 14 & 1.936312 & & & 4786856 & & 5.456758 & 0.4072 & 1.82857 & 113.9 & 179.5 \\
\hline & 14 & E-04 & - & - & $\begin{array}{c}4.186856 \\
E-06\end{array}$ & - & E-06 & 0.4072 & $1 \mathrm{E}-04$ & 6 & 0 \\
\hline & & 8.552489 & & & & - & 6.858746 & & 1.85852 & 115.8 & 169.9 \\
\hline & 10 & E-05 & - & - & - & $\begin{array}{c}\text { E-05 } \\
\end{array}$ & E-06 & 0.3016 & $2 \mathrm{E}-04$ & 3 & 2 \\
\hline & & 2.44528 & 1.10443 & -4.18115 & & -3.99301 & & 0.7332 & 1.25004 & & 127.2 \\
\hline & 10 & E-04 & E-05 & E-06 & - & E-05 & - & 4 & $6 \mathrm{E}-04$ & 11.51 & 6 \\
\hline & 17 & 2.750926 & $7.4174 \mathrm{E}-$ & & & & 6.190508 & 08224 & 1.01987 & 6356 & 126.3 \\
\hline & 11 & $E-04$ & 06 & $E-06$ & 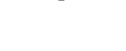 & - & E-06 & $0.0<<4$ & 9 E-04 & 00.00 & 3 \\
\hline & 18 & -1.85085 & 1.53776 & & 4.51508 & -4.25666 & & 0.7370 & 1.24118 & 7736 & 128.9 \\
\hline & 10 & E-04 & E-05 & & E-06 & E-05 & - & 1 & $3 \mathrm{E}-04$ & 11.00 & 6 \\
\hline & 19 & -5.756989 & $1.59086 \mathrm{E}$ & & 8.545435 & & 6.118719 & 08257 & 1.01053 & 6298 & 126.2 \\
\hline & 10 & E-04 & -05 & 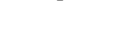 & E-06 & & E-06 & 0.0208 & 7 E-04 & 02.00 & 7 \\
\hline Three & 20 & -1574577 & 1.158095 & & & 2.951754 & 3.489908 & 7102 & 1.21176 & $755 ?$ & 142.5 \\
\hline & 20 & $E-04$ & E-05 & - & - & $E-05$ & E-06 & 0.1450 & $4 \mathrm{E}-04$ & 15.02 & 3 \\
\hline & 21 & 1.35227 & & -1.52656 & -1.09061 & -4.36717 & & 0.7225 & 1.27482 & 79.45 & 127.4 \\
\hline & 21 & E-03 & - & E-05 & E-05 & E-05 & - & 6 & $6 \mathrm{E}-04$ & 19.45 & 6 \\
\hline & & 1.009944 & & - & - & & 6.379831 & & 1.02989 & & 126.3 \\
\hline & 22 & E-03 & - & 1.598651 & 7.274619 & - & E-06 & 0.8189 & $8 \mathrm{E}-04$ & 64.19 & 9 \\
\hline & & & & $E-05$ & & & & & & & \\
\hline & & 7.132345 & & - & & - & 9.069924 & & 1.22684 & & 147.7 \\
\hline & 23 & E-04 & - & 1.463007 & - & 49705 & E-06 & 0.1430 & $3 \mathrm{E}-04$ & 10.46 & 5 \\
\hline
\end{tabular}

solavtariq@yahoo.com; muhammad.fatttah@ univsul.edu.iq 


\begin{tabular}{|c|c|c|c|c|c|c|c|c|c|c|c|}
\hline & 24 & $\begin{array}{c}2.262727 \\
\text { E-04 }\end{array}$ & - & - & $\begin{array}{c}3.93828 \mathrm{E} \\
-06 \\
\end{array}$ & $\begin{array}{c}3.829383 \\
E-05 \\
\end{array}$ & $\begin{array}{c}5.171677 \\
\text { E-06 }\end{array}$ & 0.4130 & $\begin{array}{c}1.85438 \\
6 \mathrm{E}-04\end{array}$ & $\begin{array}{c}115.5 \\
7\end{array}$ & $\begin{array}{c}174.6 \\
3\end{array}$ \\
\hline & 25 & $\begin{array}{c}3.105747 \\
E-04\end{array}$ & $\begin{array}{c}7.142926 \\
E-06\end{array}$ & $\begin{array}{c}8.738223 \\
E-06\end{array}$ & - & $\begin{array}{c}1.207676 \\
E-05\end{array}$ & $\begin{array}{c}6.101595 \\
E-06\end{array}$ & 0.8230 & $\begin{array}{c}1.03841 \\
4 \mathrm{E}-04\end{array}$ & 64.72 & $\begin{array}{c}126.8 \\
9\end{array}$ \\
\hline \multirow[t]{2}{*}{$\begin{array}{c}\text { Four } \\
\text { parameters }\end{array}$} & 26 & $\begin{array}{c}-5.617985 \\
E-04\end{array}$ & $\begin{array}{c}1.585881 \\
E-05\end{array}$ & - & $\begin{array}{c}8.802467 \\
E-06\end{array}$ & $\begin{array}{c}1.348241 \\
E-05\end{array}$ & $\begin{array}{c}6.016277 \\
E-06\end{array}$ & 0.8264 & $\begin{array}{c}1.02846 \\
2 \mathrm{E}-04\end{array}$ & 79.86 & $\begin{array}{c}126.8 \\
9\end{array}$ \\
\hline & 27 & $\begin{array}{c}1.018576 \\
E-03\end{array}$ & - & $\begin{array}{c}- \\
1.593626 \\
E-05\end{array}$ & $\begin{array}{c}- \\
6.975672 \\
E-06\end{array}$ & $\begin{array}{c}- \\
1.31378 \mathrm{E} \\
-05\end{array}$ & $\begin{array}{c}6.279124 \\
E-06\end{array}$ & 0.8196 & $\begin{array}{c}1.04835 \\
E-04\end{array}$ & 65.34 & $\begin{array}{c}127.0 \\
0\end{array}$ \\
\hline
\end{tabular}

Table (1): Regression coefficients for the relationship between saturated hydraulic conductivity and selected soil properties along with several efficiency criteria.

Table (2): Descriptive statistics of physical and chemical properties of the 30 soil samples used to verify the saturated hydraulic conductivity models.

\begin{tabular}{cccccc} 
Variable & Mean & Min & Max & SD & CV \\
\cline { 2 - 4 } & \multicolumn{2}{c}{$\left({\left.\mathrm{g} 100 \mathrm{~g}^{-1}\right)}^{2}\right.$} & $\%$ \\
Sand & 15.47 & 2.0 & 64.0 & 14.98 & 96.82 \\
Silt & 46.73 & 25.0 & 76.0 & 9.67 & 20.70 \\
Clay & 37.9 & 10.0 & 59.0 & 14.54 & 38.37 \\
$\mathrm{CaCO}_{3}$ & 27.17 & 5.08 & 84.6 & 16.27 & 59.90 \\
$\mathrm{OM}$ & 1.49 & 0.4 & 2.8 & 0.615 & 41.27
\end{tabular}

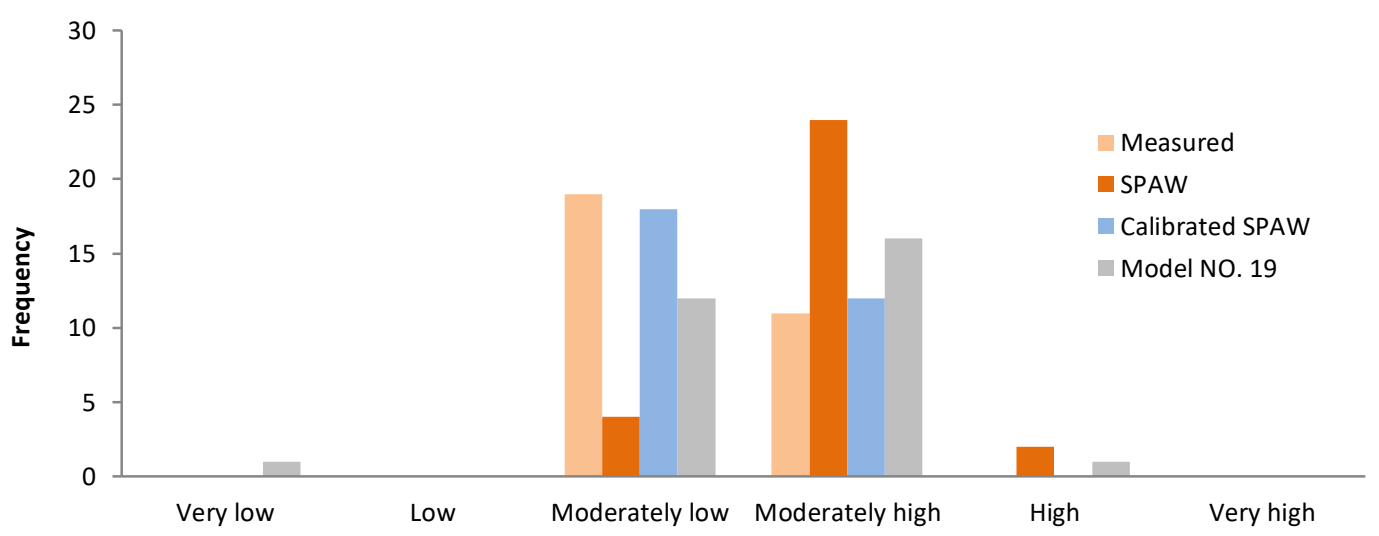

Fig. (2): Frequency distribution of the soil samples according to the measured values of saturated hydraulic conductivity and values predicted by SPAW model, calibrated SPAW model, and model number 19. 


\begin{tabular}{cccccccc} 
& \multicolumn{2}{c}{$\mathbf{K}_{\mathbf{s}}$ at loose state } & \multicolumn{3}{c}{$\mathbf{K}_{\mathbf{s}}$ at loose to normal state } & \multicolumn{2}{c}{$\mathbf{K}_{\mathbf{s}}$ at normal state } \\
\cline { 2 - 10 } $\begin{array}{c}\text { Efficiency } \\
\text { criteria }\end{array}$ & $\begin{array}{c}\text { Measured vs. } \\
\text { SPAW }\end{array}$ & $\begin{array}{c}\text { Measured } \\
\text { vs. } \\
\text { calibrated } \\
\text { SPAW }\end{array}$ & $\begin{array}{c}\text { Measured vs. } \\
\text { SPAW }\end{array}$ & $\begin{array}{c}\text { Measured vs. } \\
\text { calibrated } \\
\text { SPAW }\end{array}$ & $\begin{array}{c}\text { Measured } \\
\text { vs. } \\
\text { model 19 }\end{array}$ & $\begin{array}{c}\text { Measured } \\
\text { vs. } \\
\text { SPAW }\end{array}$ & $\begin{array}{c}\text { Measured } \\
\text { vs. } \\
\text { calibrated } \\
\text { SPAW }\end{array}$ \\
\hline RMSE & $3.403 \mathrm{E}-04$ & $1.210 \mathrm{E}-04$ & $2.664 \mathrm{E}-04$ & $9.822 \mathrm{E}-05$ & $9.738 \mathrm{E}-05$ & $1.241 \mathrm{E}-04$ & $1.175 \mathrm{E}-04$ \\
AAPE & 354.59 & 104.02 & 222.03 & 84.20 & 126.27 & 119.68 & 100.45 \\
CV & 212.07 & 75.40 & 166.04 & 61.21 & 60.69 & 77.36 & 73.24 \\
EF & -1.1286 & 0.7309 & -0.3049 & 0.8227 & 0.8257 & 0.7167 & 0.7461 \\
CRM & -1.473 & $-2.113 \mathrm{E}-04$ & -0.951 & $2.259 \mathrm{E}-04$ & $-4.325 \mathrm{E}-15$ & -0.149 & $1.350 \mathrm{E}-02$ \\
MAE & $2.461 \mathrm{E}-04$ & $7.948 \mathrm{E}-05$ & $1.712 \mathrm{E}-04$ & $6.320 \mathrm{E}-05$ & $7.885 \mathrm{E}-05$ & $7.705 \mathrm{E}-05$ & $7.638 \mathrm{E}-05$ \\
\hline
\end{tabular}

Table (3): Comparison between measured and predicted $\mathrm{K}_{\mathrm{s}}$ by SPAW and calibrated SPAW model based on selected efficiency criteria

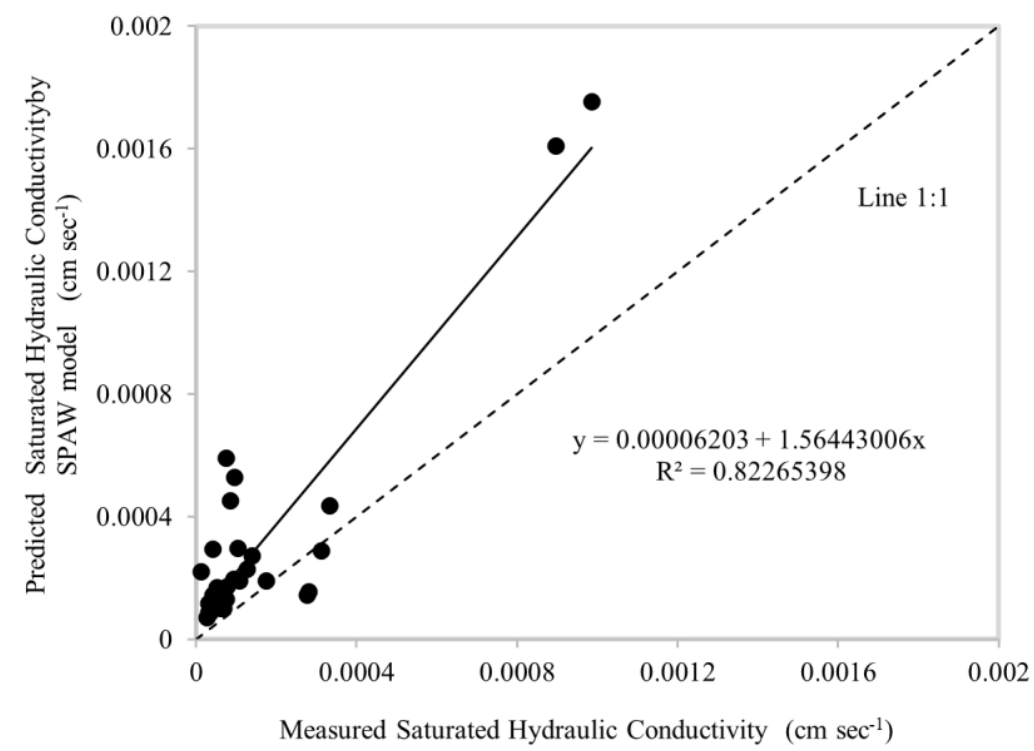

Fig. (3): Relationship between measured saturated hydraulic conductivity values and values predicted by SPAW models for loose to normal soil compaction state. 


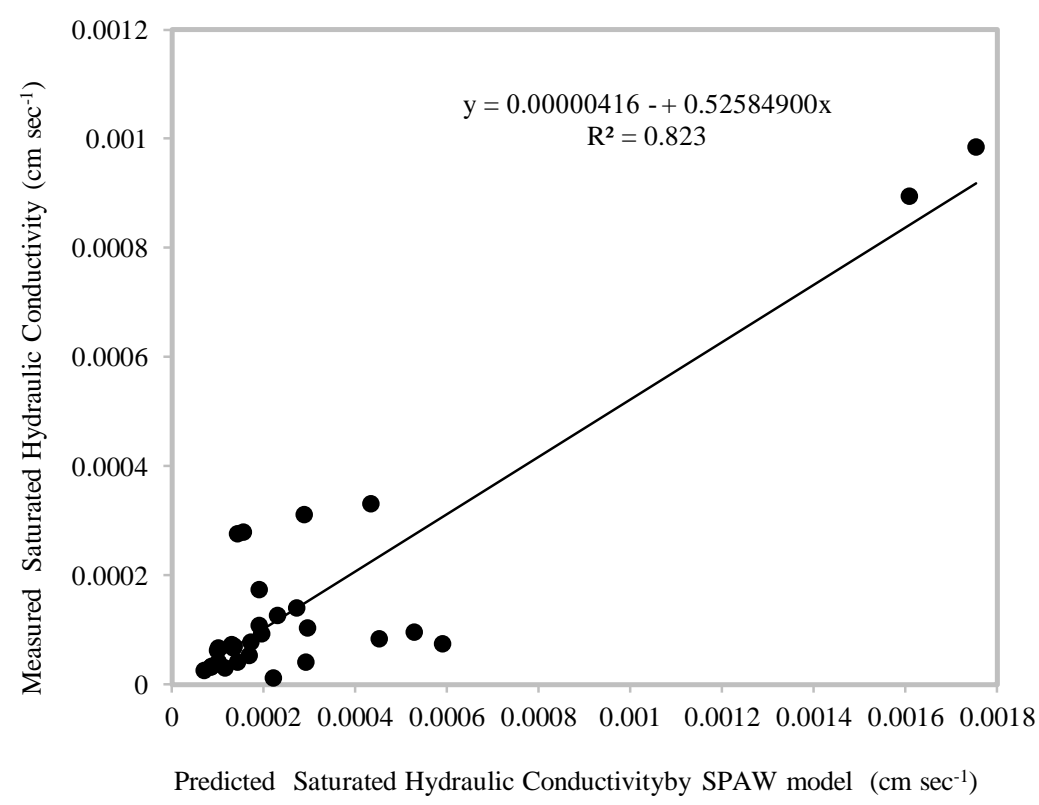

Fig. (4): Relationship between predicted saturated hydraulic conductivity values by the SPAW model and measured values (calibrated SPAW model) for loose to normal state.

The results also indicate that more than $82 \%$ of the variation in actual $\mathrm{K}_{\mathrm{s}}$ values is attributed to variation in the SPAW model predicted values. Additionally, the plot of $\mathrm{K}_{\mathrm{s}}$ SPAW,cal versus $\mathrm{K}_{\mathrm{s}}$ SPAW in relation to line 1:1 shows that most of the data points fall under the indicated line (Fig. 5). This means that the values of $\mathrm{K}_{\mathrm{s}}$ predicted by the SPAW model are overestimated for calcareous soils, particularly in the high range of hydraulic conductivity values. In other words, the accuracy of the SPAW model for predicting $\mathrm{K}_{\mathrm{s}}$ will decrease with increasing hydraulic conductivity in calcareous soils. This may be due to precipitation of crystallitic in the clayey micromass and calcitic coatings around quartz minerals (Monger et al., 1991). Consequently the pore space among soil particles and aggregates this can lead to reducing the size and number of the pores in the soil which, in turn, can lead to a severe reduction in the soil's hydraulic conductivity.

Also, from calibrated SPAW model it can be noted that the slope coefficient was about 0.5 which means the actual values of $\mathrm{K}_{\mathrm{s}}$ are approximately equal to half of the $\mathrm{K}_{\mathrm{s}}$ values predicted by the SPAW model. Furthermore, Table 3 reveals that upon calibration the value of RMSE dropped from 2.664E-04 to $9.822 \mathrm{E}-05 \mathrm{~cm} \mathrm{~s}^{-1}$. The results also indicate that the modeling efficiency attained a positive value and moved closer to 1.0 due to calibration. Its value increased from -0.305 to 0.823 . The closer the model efficiency is to 1.0 , the more accurate is the model (Nash and Sutcliffe, 1970). The positive value of CRM indicates that the calibrated model tended to underestimate the $\mathrm{K}_{\mathrm{s}}$ values. This is also evident from Table 3 . The MAE dropped from $1.712 \mathrm{E}-04$ to $6.320 \mathrm{E}-05 \mathrm{~cm}$ $\mathrm{s}^{-1}$ due to calibration. Similarly, it can be observed that the AAPE dropped from 222.03\% to $84.23 \%$, while the $\mathrm{CV}$ decreased from about $166.04 \%$ to about $61.21 \%$. Since the predicted values of $\mathrm{K}_{\mathrm{s}}$ from the calibrated model have a higher degree of accuracy compared with the non-calibrated values, the $\mathrm{K}_{\mathrm{s}}$ values for calcareous soils obtained by the SPAW model should be modified. Accordingly, the calibration of the SPAW model is necessary. Finally, the calibrated model may permit a significant reduction in labor and time required to predict $\mathrm{K}_{\mathrm{s}}$ values.

$$
\text { solavtariq@yahoo.com; muhammad.fattah@univsul.edu.iq }
$$




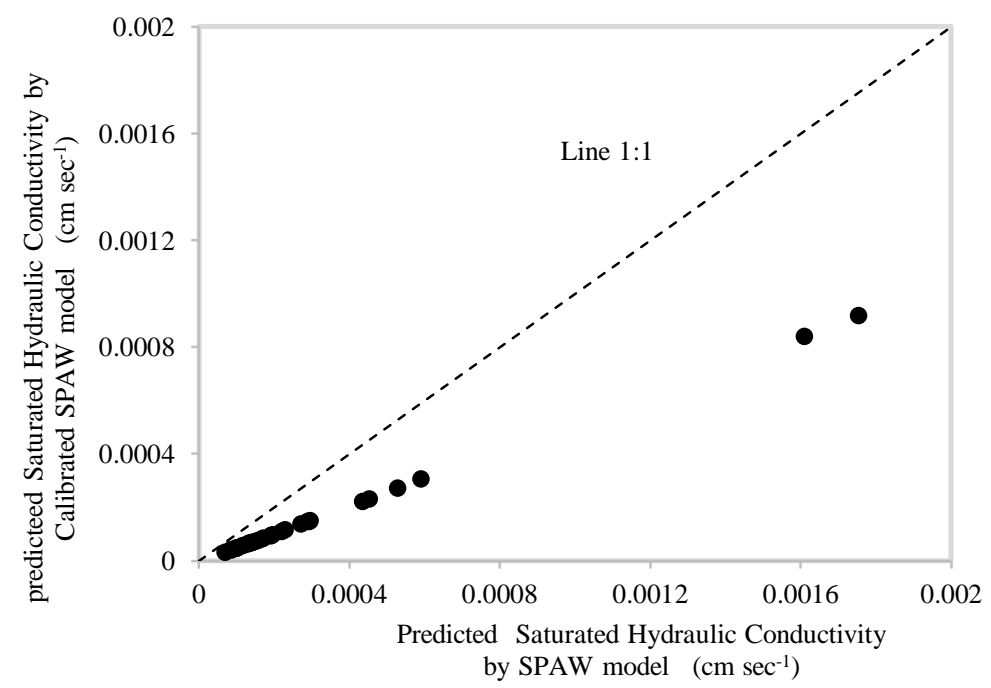

Fig. (5): Relationship between predicted saturated hydraulic conductivity values by the calibrated SPAW model and predicted saturated hydraulic conductivity values by the SPAW model for loose to normal state.

\subsection{Test of Performance of the SPAW Model for Predicting Saturated Hydraulic Conductivity under Different Degrees of Soil Compaction}

In order to identify the state under which the SPAW model offered the best performance, the predicted saturated hydraulic conductivity of the soil samples under different degrees of compaction (loose, loose to normal, and normal) were compared with the corresponding measured values and the results presented in Figures 4, 6, and 7. It is evident from these figures that predicted $\mathrm{K}_{\mathrm{s}}$ for soils with a loose to normal state of compaction offered the highest degree of matching with measured values, indicating that the state of sampled soil during the laboratory measurement was more close to the loose to normal state compared to the other states. Under this state, the variation in $\mathrm{K}_{\mathrm{s}}$ value predicted by the SPAW model explained more than $82 \%$ of the variation in measured $\mathrm{K}_{\mathrm{s}}$ values. In contrast, less than $75 \%$ of the variation in measured $\mathrm{K}_{\mathrm{s}}$ was attributed to variation in predicted $\mathrm{K}_{\mathrm{s}}$ under the other compaction states. 


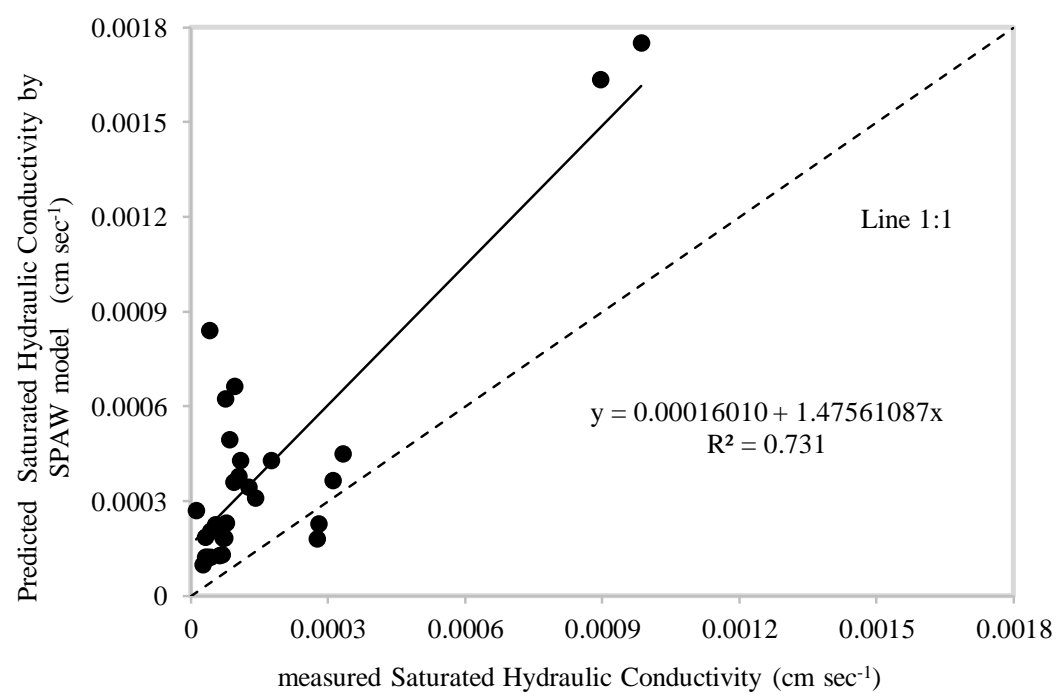

Fig. (6): Relationship between measured saturated hydraulic conductivity values and values predicted by the SPAW model for loose soil.

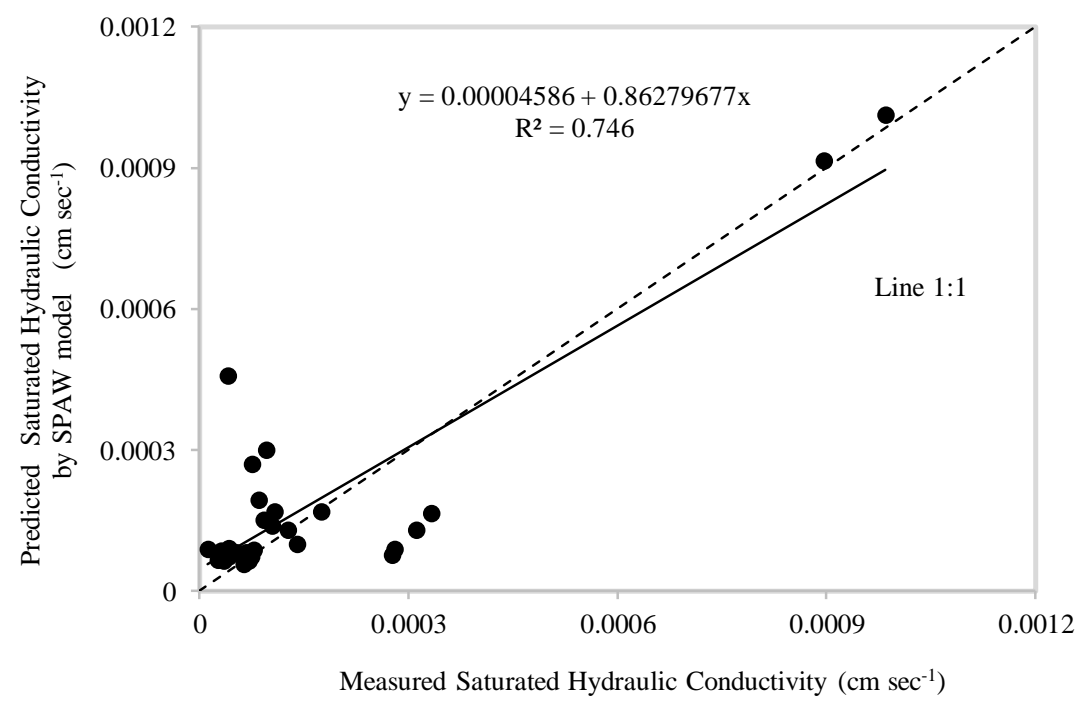

Fig. (7): Relationship between measured saturated hydraulic conductivity values and values predicted by the SPAW model for normal soil.

\section{CONCLUSIONS}

Comparison of the measured $\mathrm{K}_{\mathrm{s}}$ to the predicted values from the SPAW model under different states of compaction indicated that the closest agreement was achieved between the measured $\mathrm{K}_{\mathrm{s}}$ and predicted values from SPAW when the soils were under a loose to normal state. However, it is recommended to use the calibrated SPAW model for predicting $\mathrm{K}_{\mathrm{s}}$ in calcareous soils because the values of $\mathrm{K}_{\mathrm{s}}$ predicted by the SPAW model are overestimated for these soils. This may be due to precipitation of crystallitic in the clayey micromass and calcitic coatings around quartz minerals. For calcareous soils in a loose to normal compaction state, the performance of the pedotransfer function, which was developed from three parameters (sand, clay, $\mathrm{CaCO}_{3}$ ) to predict $\mathrm{K}_{\mathrm{s}}$ was better than the performance of the SPAW model.

$$
\text { solavtariq@yahoo.com; muhammad.fattah@univsul.edu.iq }
$$




\section{REFERENCES}

AAFRD (Alberta Agriculture Food and Rural Development) (1996) Seepage control in dugouts. Agdex 716 (B32). Practical information for Alberta's Agriculture industry or Agricultural Engineering; Alberta Agriculture, Food and Rural Development regional engineering technologists.

Abedakarim KO (2015) Calcareous soils identification using geoinformatic technique in Sulaimani governorate, Iraqi Kurdistan Region. Master Thesis, Soil and Water Sciences Department. University of Sulaimani, Iraq.

Ahmadi SH, Sepaskhah AR (2012) Prediction of saturated hydraulic conductivity of compacted soils using empirical scaling factors. Arch Agron Soil Sci 58:1303-1316.

Aziz F (2002) Zoning and subzoning of Arbil mountains. AEZ Consultancy Report No. 3. FAO Representation in Iraq. FAO Coordinate Office for Northern Iraq, Erbil.

Bouma J (1989) Using soil survey data for quantitative land evaluation. In advances in soil science. Springer-Verlag New York Inc. 9;177-213.

Brakensiek DL, Rawls WJ, Stephenson GR (1986) Determining the Saturated Hydraulic Conductivity of a Soil Containing Rock Fragments. Soil Sci. Soc. Am. J. 50:834-835.

Burt R (2014) Soil survey field and laboratory methods manual. United States Department of Agriculture, Natural Resources Conservation Service, National Soil Survey Center, Natural Resources Conservation Service, Kellog Soil Survey Laboratory.

Durand N, Monger C, Canti M, Verrecchia P (2018) Calcium Carbonate Features. Chapter 9 Calcium Carbonate Features, Editor(s): Georges Stoops, Vera Marcelino, Florias Mees, Interpretation of Micromorphological Features of Soils and Regoliths (Second Edition), Elsevier, pp 205-258.

Faraj SH (2017) phosphorus fractionation in some calcareous soils from Sulaimani governorate.
Master thesis. Soil and Water Sciences Department, University Sulaimani, Iraq.

Igbadun HE, Oyebode MA, Mohammed AS (2011) Evaluation of a simulation model for predicting soil-water characteristics of selected agricultural fields. Nigerian Journal of Technological Development 8:61-73.

Khalaf AA (2010) Approaches to evaluate the sealing performance of local materials for seepage reduction. Submitted to College of Agriculture, University of Salahaddin, Iraqi Kurdistan Region as partial fulfillments of the requirements of $\mathrm{PhD}$ dissertation in Soil and Water Science.

Klute A (1986) Methods of soil analysis. Part 1. Physical and mineralogical methods, $2^{\text {nd }}$ edn. Agron. Monogr. 9. ASA and SSSA, Madison, WI. pp 383-411.

Krause P, Boyle DP, Base F (2005) Comparison of different efficiency criteria for hydrological model assessment. Advances in geosciences 5:89-97.

Ma Y, Feng S, Huo Z, Song X (2011) Application of the SWAP model to simulate the field water cycle under deficit irrigation in Beijing, China. Mathematical and Computer Modelling 54:1044-1052.

Monger, HC, Daugherty, LA. Gile, LH, (1991) A microscopic examination of pedogenic calcite in an Aridisol of southern New Mexico. In Nettleton, WD (ed.), Occurrence, Characteristics, and Genesis of Carbonate, Gypsum, and Silica Accumulations in Soils. Soil Science Society of America Journal Special Publication 26, Madison, pp 37-60.

Najmaddin PM, Whelan MJ, Balzter H (2017) Estimating daily reference evapotranspiration in a semi-arid region using remote sensing data. Remote Sensing 9:779-798.

Nash JE, Sutcliffe JV (1970) River flow forecasting through conceptual models part I, A discussion of principles. Journal of hydrology 10:282-290.

Nelson DW, Sommers L (1982) Total carbon, organic carbon, and organic matter. Methods of soil 
analysis. Part 2. Chemical and microbiological properties, pp 539-579.

Pachepsky Y, Van Genuchten M (2011) Chapter: Pedotransfer Functions. Editor(s): J. Glinski, J. Horabik, J. Lipiec Encyclopedia of Agrophysics. Springer 556-560.

Renard KG, Foster GR, Weesies GA, McCool DK, Yoder DC (1997) Predicting soil erosion by water: a guide to conservation planning with the Revised Universal Soil Loss Equation (RUSLE). Washington, DC: United States Department of Agriculture 703:19-64

Rowell DL (1996) Soil Science: Methods and applications. Longman Group UK Ltd. pp 5051.

Salarashayeri AF, Siosemarde M (2012) Prediction of soil hydraulic conductivity from particle size distribution. World Acad Sci Eng Technol 6:16-20.

Saxton KE, Rawls WJ (2006) Soil water characteristic estimates by texture and organic matter for hydrologic solutions. Soil Sci. Soc. Am. J. 70:1569-1578.
Song X, Wang S, Xiao G, Wang Z, Liu X, Wang P (2009) A study of soil water movement combining soil water potential with stable isotopes at two sites of shallow groundwater areas in the North China Plain. Hydrological Processes: An International Journal 23:13761388.

Stoops G (2003) Guidelines for Analysis and Description of Soil and Regolith Thin Sections. Soil Sci. Soci. Am. Madison, p 184.

Van Reeuwijk LR (1995) Procedures for soil analysis. p. 3-8 $5^{\text {th }}$ edition. International soil reference and information center, technical pp 9.

Wilding LG (1985) Soil spatial variability: Its documentation, accommodation and implication to soil surveys. In: Nielsen DR and Bouma J (Eds.). Soil Spatial Variability Proceedings of a Workshop of the ISSS and the SSA, Las Vegas PUDOC, Wageningen. pp.

166-187. 